\title{
Özengen Çalg1 Eğitimine Yönelik Güdülenme Ölçeğinin Geçerlik ve Güvenirlik Çalışması
}

\section{A Study on Validity and Reliability of the Motivation Scale for Amateur Instrument Training}

\section{Özge Gençel Ataman}

Doç .Dr., Balıkesir Üniversitesi Necatibey Eğitim Fakültesi Güzel Sanatlar Eğitimi Bölümü

email: ogencelataman@gmail.com (DORCID ID: https://orcid.org/0000-0002-4621-8609

\author{
İbrahim Güler \\ Yüksek Lisans Öğrencisi, Balıkesir Üniversitesi Sosyal Bilimler Enstitüsü \\ email: mox613@gmail.com (DORCID ID: https://orcid.org/0000-0003-4385-202x
}

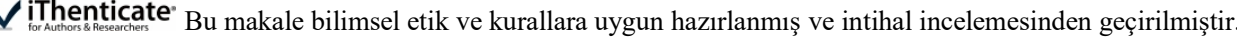 \\ Atıf (APA 6)/To cite this article \\ Gençel Ataman, Ö. \& Güler, İ. (2020). Özengen çalgı eğitimine yönelik güdülenme ölçeğinin geçerlik ve güvenirlik çalışması. Atatürk \\ Üniversitesi Güzel Sanatlar Enstitüsü Dergisi, 26(Müzik Özel Say1s1), 294-305. doi: https://doi.org/10.35247/ataunigsed.650270
}

Makale Gönderim Tarihi/Received: 23/11/2019

Makale Kabul Tarihi/Accepted: 25/02/2020

Makale Yayın Tarihi/Published: 25/03/2020

Research Article / Araștırma Makalesi

\section{$\ddot{O} z$}

Bu çalıșmanın amacı, özengen çalgı eğitimi alan bireylerin, özengen çalg1 eğitimine yönelik güdülenme durum ve düzeylerinin belirlenebilmesinde araç olarak kullanılabilecek bir güdülenme ölçeği geliştirmektir. Araştırmanın çalışma grubu, Çanakkale ve Balıkesir illerindeki resmi ve özel yaygın eğitim kurumlarında özengen çalgı eğitimi almakta olan 280 katılımcıdan oluşmaktadır. Ölçek geliştirme aşamasında özengen çalg1 eğitimine yönelik 47 güdülenme maddesi olușturulmustur. Geliştirilmeye çalışılan ölçme aracının geçerlik ve güvenirliğini belirlemek amacıyla madde analizi ve açımlayıcı faktör analizinden yararlanılmıștır. Madde analizinde madde-test korelasyon katsayısı düşük olan ve açımlayıcı faktör analizi sonucunda birden fazla faktörde binişik yapıda olan maddeler ölçekten çıkarılmıştır. Yeniden yapılan açımlayıcı faktör analizi sonuçlarına göre, 25 maddeden oluşan ölçeğin 5 faktörlü bir yapıda olduğu ve faktörlerin toplam varyansın \% 54.305'ini açıkladığı belirlenmiştir. Faktörler altına yüklenen maddeler ve kuramsal beklentiden yola çıklarak ölçekteki faktörler; Mutluluk, isteksizlik, zorluk yaşama, sosyal çevreyle etkileşim ve ilgi olarak adlandırılmıştır. 5 faktör altında yer alan 25 maddelik ölçeğin tümü için Cronbach Alfa güvenirlik katsayısı 0.877 bulunmuştur. Özengen çalgı eğitimine yönelik güdülenme ölçeğinin psikometrik özellikleri dikkate alındığında, özengen çalg1 eğitimi alan bireylerin bu eğitime yönelik güdülenmelerinin ölçülmesinde geçerli ve güvenilir bir şekilde kullanılabilecek bir ölçme aracının geliștirildiği düşünülmektedir.

Anahtar kelimeler: Özengen Çalgı Eğitimi, Güdülenme, Ölçek, Geçerlik, Güvenirlik

\begin{abstract}
The aim of this study is to develop a motivation scale which can be used as a tool to determine motivation status and levels of individuals who take amateur instrument training. The study group of the study consists of 280 participants who have taken amateur instrument training in public and private non-formal education institutions in Canakkale and Balıkesir. During the scale development stage, 47 motivational items were created for the amateur instrument training. In order to determine the validity and reliability of the measurement tool, item analysis and exploratory factor analysis were used. In item analysis, items with low itemtest correlation coefficients and as a result of exploratory factor analysis, items with overlapping factors were removed from the scale. According to the results of the reconstructive exploratory factor analysis, it was determined that the scale consisting of 25 items had a 5-factor structure and the factors explained \% 54.305 of the total variance. The items loaded under the factors and the factors in the scale based on theoretical expectations; Happiness, reluctance, difficulty, interaction with the social environment and interest was named. The Cronbach's alpha reliability coefficient was found to be 0.877 for the 25 item scale under 5 factors. Considering the psychometric properties of amateur instrument training motivation scale, it is considered that a valid and reliable measurement tool has been developed to measure the motivation of individuals who have taken amateur instrument training.
\end{abstract}

Keywords: Amateur Instrument Training, Motivation, Scale, Validity,Reliability

\section{Giriş}

Müzik eğitimi; genel müzik eğitimi, mesleki müzik eğitimi ve özengen (amatör) müzik eğitimi olmak üzere üc şekilde sınıflandırılmaktadır. Genel müzik eğitimi; eğitim yaşantısı süreci içinde tüm bireylere, mesleki müzik eğitimi; müziği meslek edinmek isteyenlere, özengen müzik eğitimi ise müzikten zevk almak, doyum sağlamak, ilgi ve istekleri doğrultusunda sanatsal yönünü geliştirmek isteyen bireylere yöneliktir (Uçan, 2005, s. 8). Bingöl (2010)'e göre müzik eğitimi yalnızca müziği meslek edinmek isteyen bireylere yönelik bir eğitim olarak görülmemektedir (s. 23). Bu bağlamda müzik eğitimi, müziğe ilgi duyan, müzik eğitimi için maddi ve manevi fedakârlı yapmaya gönüllü olan ve müzik eğitimi almaya özenen herkesin belirli bir düzeyde gerçekleştirebileceği bir eğitimdir. Bir başka açıdan özengen müzik eğitimi, eğitim süreçlerinde genel müzik eğitimi almış ve mesleki müzik eğitimi alarak müziği meslek edinmeyi amaçlayan bireylerin hedeflerini 
sağlamalarına olanak sağlayan bir müzik eğitimi türü olarak da düşünülebilmektedir (Çağlar, 2017, s. 114). İşte bu noktada da özengen müzik eğitimi, bireylerin müzik yaşantılarında önemli bir yer tutmaktadır.

Örgün ve yaygın eğitim içinde yer alan özengen müzik eğitimi, gerekli müziksel davranışları kazandırma yoluyla bireylerin müzik eğitiminden zevk ve doyum sağlamalarını amaçlar. Özengen müzik eğitimi örgün eğitim kapsamındaki, ilköğretim, ortaöğretim ve yükseköğretimde; eğitsel kol çalışmaları, seçmeli dersler, ses ve çalg1 toplulukları, isteğe bağlı düzenlenen bireysel ve toplu müzik kursları ile gerçekleşmektedir. Yaygın eğitimde ise özel kuruluşların düzenledikleri kurslar, özel dersler, konserler, festivaller, yarışmalar özengen eğitim için oldukça önemli bir yere sahiptir (Uçan, 2005, s. 32).

Ülkemizde giderek önem kazanmakta olan özengen müzik eğitimi, yaygın eğitim açısından bireysel yapılabildiği gibi kurumsal olarak da halk eğitim merkezleri gibi resmi kurumlarda ve özel müzik kursları gibi özel kurumlarda yürütülmektedir. Bu kurumlarda özengen müzik eğitimi, hem müziğe yeni başlayanlar hem de müzikte belli bir seviyede olup kendini daha ileri bir seviyeye taşımak isteyenler için belirli eğitim programları çerçevesinde farklı seviyelerde verilmektedir. Ayrıca bu kurumlar, hem müziği amatörce düşünenlere hem de ileride profesyonel olmayı tasarlayanlara eğitim hizmeti vererek ülkemiz müzik eğitimine de önemli katkılar sağlamaktadır (Özdek, 2006, s. 16; Karan, 2011, s. 9; Tepeli, 2018, s. 32).

Müzik eğitimi alanında çok önemli bir yere sahip olan çalgı eğitimi de, genel, mesleki ve özengen müzik eğitimi türlerinde aynı öneme sahiptir. Özengen çalgı eğitimi, bireylerin gönüllülük esasına dayalı olarak müzikal tatmin ve kültürel gelişim sağlayan en önemli sosyal aktivitedir. Mesleki çalgı eğitiminin teknik ve müzikal öğelerini barındırarak, bireylere ilgi alanı, estetik duygu ve müzikal bir gelişim sağlamayı görev edinir. Ancak Cope (2002)'un da belirttiği gibi özengen çalgi eğitimi, üst düzey disiplin gerektiren ve tekniğe yoğunlaşan mesleki çalg1 eğitiminin aksine çok resmi olmayan bir süreçte yetkin amatör müzisyenler yetiştirmeyi amaçlamaktadır (s. 93).

Seah ve Bishop (2000)'a göre öğretim ortamlarında yalnızca bilişsel ve devinişsel becerilere yer verilmesi, başarılı bireyler yetiştirilmesi için yeterli değildir (s. 2). Bireylerin başarılı olabilmesi için bilişsel becerilerin yanında duyuşsal beceriler de büyük önem taşımaktadır. Duyuşsal alan becerilerini etkileyen güdülenme de öğretim faaliyetlerinin gerçekleşmesinde görev alan en önemli öğelerden birini oluşturmaktadır. Arık (1996) güdülenmeyi, "insanı davranışa iten, bu davranışın şiddet ve enerji düzeyini belirleyen, davranışlara belirli bir yön veren ve devamını sağlayan, çeşitli "iç ve dış sebepleri”" ve bunların işleyiş mekanizmalarını içeren karmaşık yapılı bir özellik” olarak açıklamaktadır. Güdülenmede; davranışa karşı hazır olma, bir amaca ulaşmak için gerekli davranışları yapma ve amaca ulaştıktan sonra doyurulma olmak üzere üç durum söz konusudur. Bu nedenle bireyde güdülenmenin varlığı, davranışlara bakılarak anlaşılmakta ve davranışlardan çıkarılmaktadır (aktaran, Sungurtekin, 2010, s. 30). Morgan (1984)'a göre güdülenme, bir hedefe yönelmiş herhangi bir davranış1 içermekte olup döngü özelliğine sahiptir (aktaran Semerci, 2010, s. 2124). Güdülenme, bireylerin istek, arzu, ihtiyaç, dürtü ve ilgilerini kapsamaktadır (Koçel, 2014, s. 619). Güdülenme, öğrenmeye ilgi duyma, geliştiğini hissetme, başarma duygusu, bireyin diğer bireyler tarafindan takdir edilmesi, çevredeki bireylerin ilgisini hissetme ve ödül kazanma gibi etmenlerden oluşmaktadır (Ryan \& Deci, 2000, s. 55). Bu bağlamda güdülenme, öğrenmeye ilgi, başarma duygusu gibi içsel etkenlerden, aile ve akran grubu tarafından takdir ve ilgi hissetme gibi dişsal etkenlerden etkilenmektedir (Sichivitsa, 2007, s. 55).

Eğitim açısından güdülenme, bireylerin öğrenme sürecinde başarılı olabilmek için, öğrenmeye katılmasını, öğrenmeye istekli olmasını ve öğrenme ihtiyacı duymasını sağlayan ve bireye enerji veren bir güçtür (Feng \& Tuan, 2005, s. 463). Başarı gereksinimi duyan bireylerin, başarılı olma yolundaki uğraşlarıdır (Bakırcığlu, 2012, s. 594). Martin (2004) eğitim açısından güdülenmeyi, öğrencilerin potansiyellerini açığa çıkaran, öğrenme ve çalışmaları harekete geçiren güç olarak açıklamaktadır (s. 6).

Güdülenme, eğitim alanında çok önemli bir yere sahip olan müzik eğitiminde de araştırmacılar ve uygulayıcılar için çok önemli bir araştırma alanıdır. Son yıllarda müzik eğitimi ile ilgili yapılan çalışmalarda müzik ve güdülenme ilişkisi dikkat çekmeye başlamıştır. Güdülenme, müzikte ürün ve yaratıcılık açısından en önemli koşullardan biri olarak kabul edilmektedir (Leung, 2008, s. 48). Müzik eğitiminin en önemli dallarından biri olan çalgı eğitimi de çalgı eğitimi alan bireylerin güdülenme durum ve düzeylerinden etkilenmektedir. Şen ve Çoban (2018)'a göre müzik sanatının ifadesinde önemli bir yeri olan çalgı eğitimi, bilişsel, duyuşsal ve devinişsel davranışların birleşimi olarak hedeflenen amaçlara ulaşmayı planlayan bir eğitim sürecidir (s. 290). İster genel, ister mesleki, ister özengen olsun çalgı eğitimi, devinişsel ve bilişsel davranışları aynı önemde kapsamanın yanında bireylerin kendilerini özgürce ifade etmeleri ve başarma duygusu hissetmeleri gibi psikolojik gereksinimlerle etkileşim içindedir. Psikolojik bir süreç olarak tanımlanan güdülenme de çalgı eğitimini etkileyen ve çalgı eğitiminden etkilenen bir olgudur. Evans (2015) çalgı eğitiminde güdülenmeyi, "bireylerin neden ve niçin çalgı öğrenmeye çalıştıkları, çalgı öğrenme sürecinde yaşadıkları zorlukları, nasıl başarılı oldukları ve çalgı öğrenmeyi niçin bıraktıkları gibi sorulara verilecek cevaplarda aramak gerektiği şeklinde açıklamaktadır (s. 65). Günal (1999), çalgı eğitimi ve güdülenme arasındaki ilişkiyi, "çalgı eğitiminde, sistemli 
olma, disiplin ve sürekli çalışma bir ön koşuldur. Böyle zor bir çalışma süreci ise ancak yoğun istek veya başka bir deyişle yüksek düzeyde bir motivasyonla sağlanabilir”' şeklinde açıklamaktadır (aktaran Çoban \& Çalışkan, 2019, s. 102).

Her alanda olduğu gibi çalg1 eğitimi alanında da ölçme önemli görülmektedir. Gözlenen değişkenlere ilişkin gözlem sonuçlarının nicel verilere dönüştürülmesi anlamını taşıyan ölçme, araştırmacılara sonuca varma aşamasında büyük kolaylıklar sağlamaktadır. Bu nedenle özellikle duyuşsal alana ilişkin davranışların ölçülmesinde ölçeklerden yararlanılmaktadır. Arık (1996)'a göre, bilimsel bilgi elde edebilmek için neyin araştırılacağını açık ve net bir şekilde ifade eden bir problemden yola çıkılarak standartlaştırılmış, güvenirliğine ve geçerliğine özen gösterilmiş ölçeklerle ölçüm yapılması gerekmektedir (aktaran Semerci, 2010, s. 2124). Duyuşsal alan davranışlarıyla ilişkili olan güdülenme düzeyi de ölçekler yardımıyla ölçülebilmektedir.

Çalg1 eğitimi, planlı, disiplinli ve sistematik bir şekilde gerçekleşmesi gereken bir süreçtir. Bu şekilde gerçekleşmesi gereken çalg1 eğitimi sürecinde de bireylerin güdülenme düzeyi başarıya ulaşmada en önemli unsurlardan biri olarak görülmektedir. Yalnızca mesleki çalgı eğitiminde değil özengen yani amatör çalgı eğitiminde de durum aynıdır. Özengen çalgı eğitiminde yaş sınırlamasının olmaması, her yaştan bireyin çalgı öğrenebilmesini ve çalgı öğrenmenin sosyal etkinlik, eğlence ve kişisel tatmin olarak gerçekleşmesini sağlamaktadır.

\subsection{Araştırmanın Amacı ve Önemi}

Özengen çalg1 eğitimi, bireylerin istek, beklenti, talep, müziğge yatkınlık, beceri düzeyi ve çalışmak için ayırdı̆̆ zaman doğrultusunda şekillenmektedir. Bireylerin ilgi ve zevkleri doğrultusunda iş-akademik ve sosyal yaşantılarından zaman ayırarak sürdürdükleri özengen çalgı eğitimi, mesleki zorunluluk taşımadığı için de kolaylıkla vazgeçebilecekleri bir etkinlik olarak düşünülebilmektedir. Bu nedenle özengen çalgı eğitimi alan bireylerin çalgı eğitimine yönelik güdülenme düzeylerinin belirlenmesi önem taşıyan ve araştırılması gereken bir konudur. Bu doğrultuda çalışmanın amacı; özengen çalgı eğitimi alan bireylerin, özengen çalgı eğitimine yönelik güdülenme durum ve düzeylerinin belirlenebilmesinde araç olarak kullanılabilecek bir güdülenme ölçeği geliştirmektir.

Çalgı eğitimi ile ilgili literatür tarandığında, çalgı eğitimine yönelik geliştirilen güdülenme ölçeklerine rastlamak mümkündür. Ancak bu ölçekler, mesleki çalg1 eğitime yönelik olarak geliştirilmiştir. Ulusal ve uluslararası literatürde spesifik olarak özengen çalgı eğitime yönelik güdülenme ölçeğine rastlanılmamıştır. Özengen çalg1 eğitiminde yaş sınırlamasının olmaması, çalgı öğrenmenin sosyal etkinlik, eğlence ve kişisel tatmin olarak gerçekleşmesi ve erişilmesi planlanan hedef ve beceri düzeyleri bakımından daha esnek ve kişiye özel olması, özengen çalg1 eğitimini mesleki çalg1 eğitiminden ayıran en önemli özelliklerdir. Bu bakımdan, özengen çalg1 eğitimi alan bireylerin güdülenme düzeylerinin, mesleki çalgı eğitimine yönelik ölçeklerle sağlıklı bir şekilde ölçülemeyeceğinden yola çıkılarak, yalnızca özengen çalg1 eğitimi alanına yönelik bir güdülenme ölçeğinin geliştirmesine ihtiyaç duyulmuştur.

\section{Yöntem}

Bu çalışma bir ölçek geliştirme çalışmasıdır. Çalışmanın ölçek geliştirme aşamasında, betimsel araştırma olarak tarama modelinden yararlanılmıştır. Bu bağlamda çalışma, betimsel modele dayalı nicel bir araştırmadır. Yaşar (2014)'ın da belirttiği gibi tarama modelli araştırmalar, bir grubun belli başlı özelliklerini belirlemek amacıyla geniş gruplarda yürütülen, bireylerin görüşlerinin belirlenerek olgu ve olayların açıklanmasına çalışılan araştırmalar olarak kabul edilmektedir (s. 62).

$\mathrm{Bu}$ araştırmanın çalışma grubu, Çanakkale ve Balıkesir illerindeki resmi ve özel yaygın eğitim kurumlarında özengen çalgı eğitimi almakta olan 280 katılımcıdan oluşmaktadır. Çalışma grubuna ilişkin demografik bilgiler Tablo 1'de verilmiştir.

Tablo 1

Çalışma grubuna ilişkin demografik bilgiler

\begin{tabular}{lcc}
\hline Cinsiyet & f & \% \\
\hline Bayan & 148 & 52.9 \\
Erkek & 132 & 47.1 \\
Toplam & 280 & 100 \\
\hline Yaş & $\mathbf{f}$ & $\mathbf{\%}$ \\
\hline 15 - 20 yaş & 88 & 31.4 \\
21 - 26 yaş & 116 & 41.5 \\
27 - 32 yaş & 44 & 15.7 \\
33 yaş ve üzeri & 32 & 11.4 \\
Toplam & 280 & 100 \\
\hline
\end{tabular}


Tablo 1'in devamı

\begin{tabular}{|c|c|c|}
\hline En son mezun olunan okul türü & f & $\%$ \\
\hline Ortaokul & 74 & 26.4 \\
\hline Lise & 148 & 52.9 \\
\hline Üniversite & 58 & 20.7 \\
\hline Toplam & 280 & 100 \\
\hline Yașanılan il & f & $\%$ \\
\hline Balıkesir & 135 & 48.2 \\
\hline Çanakkale & 145 & 51.8 \\
\hline Toplam & 280 & 100 \\
\hline Çalgı eğitimi alınan kurum tipi & f & $\%$ \\
\hline Resmi & 184 & 65.8 \\
\hline Özel & 96 & 34.2 \\
\hline Toplam & 280 & 100 \\
\hline Eğitimi alınan çalgı & f & $\%$ \\
\hline Keman & 32 & 11.4 \\
\hline Piyano & 54 & 19.2 \\
\hline Gitar & 62 & 22.3 \\
\hline Bağlama & 104 & 37.3 \\
\hline Flüt & 15 & 5.3 \\
\hline Bateri & 8 & 2.8 \\
\hline Saksafon & 5 & 1.7 \\
\hline Toplam & 280 & 100 \\
\hline
\end{tabular}

Tablo 1 incelendiğinde çalışma grubunda yer alan bireylerin \% 52.9'unun bayan, \% 47.1 'inin erkek olduğu; \% 31.4'ünün 15 - 20 yaş, \% 41.5'inin 21 - 26 yaş, \% 15.7'sinin 27 - 32 yaş, 11. 4'ünün 33 ve üzeri yaş aralığında olduğu; \% 26.4'ünün ortaokul, \% 52.9'unun lise, \% 20.7'sinin de üniversiteden mezun durumda olduğu, \% 48,2'sinin Balıkesir, \% 51.8'inin Çanakkale illerinde yaşadığı, \% 65.8'inin resmi, \% 34.2'sinin özel eğitim kurumlarında çalg1 eğitimini sürdürmekte olduğu; \% 11.4'ünün keman, \% 19.2'sinin piyano, \% 22.3'ünün gitar, \% 37.3'ünün bağlama, \% 5.3'ünün flüt, \% 2.8'inin bateri ve \% 1.7'sinin de saksafon eğitimi almakta olduğu anlaşılmaktadır.

Özengen çalg1 eğitimine yönelik güdülenme ölçeğinin analizinde SPSS Statistic 23.0 programından yararlanılmıştır. Ölçeğin geliştirme aşamasında öncelikle görünüş ve kapsam geçerliğine bakılmıştır. Kapsam geçerlik oranı (KGO) için Davis tekniği kullanılmıştır (Tablo 2). Ölçeğin güvenirliği için ölçeği oluşturan her bir maddeye ilişkin olarak madde ortalama, madde standart sapma, madde toplam korelasyon değerleri incelenmiş ve Cronbach Alfa güvenirlik katsayısı değerinden yararlanılmıştır (Tablo 3 ve Tablo 4). Ölçeğin geçerliğini ölçmek amacıyla da Kaiser-Meyer-Olkin (KMO) Örneklem Yeterliliği testi ve Barlett Küresellik testi analizlerinden (Tablo 5) elde edilen bulgular doğrultusunda açımlayıcı faktör analizi kullanılarak maddelerin varyans değerlerine (Tablo 7) ve faktör döndürme sonuçlarına (Tablo 8) yer verilmiştir. Ayrıca ölçeğin analizinde maddelerin yer aldıkları faktörlerin açıkladıkları varyans ve güvenirlik analizi sonuçlarına da yer verilmiştir (Tablo 9).

\section{Bulgular}

\section{1. Ölçeğin Geliştirilmesi}

Ölçeğin geliştirme aşamasında ilk olarak, özengen çalg1 eğitimi almakta olan 43 bireyin özengen çalg1 eğitimine yönelik görüşlerini ortaya koyabileceği yarı yapılandırılmış görüşmeler gerçekleştirilmiştir. Görüşmelerden elde edilen veriler içerik analizi yöntemi ile analiz edilmiş ve analiz sonucunda güdülenme ile ilgili görüşler maddeleştirilmiştir. Güdülenme ile ilgili görüşlerin yanında konu ile ilgili alan yazın ve güdülenme ile ilgili ölçekler de incelenerek 47 maddeden oluşan bir madde havuzu oluşturulmuştur. Ölçeğin geçerliğini sağlamak için görünüş ve kapsam geçerliğine bakılmıştır. Ölçeğin görünüş ve kapsam geçerliği için üç müzik eğitimi ve iki istatistik uzmanı olmak üzere beş öğretim üyesinin görüşüne başvurulmuştur. Uzmanlardan alınan görüşler doğrultusunda görünüş geçerliği için ölçekteki 11, 19, 20 ve 24. maddelerin yeniden düzenlenmesine karar verilmiştir. Belirtilen maddeler tekrar düzenlendiğinde, ölçme aracının amaca uygun olduğu, gerekli verileri toplayabileceği ve istenilen özelliği ölçer göründüğü sonucuna varılmıştır. Ölçeğin kapsam geçerliğine ilişkin olarak Davis tekniğinden yararlanılmıştır. Yurdugül (2005)'ün de belirttiği gibi Davis tekniği uzman görüşlerini (a) "Uygun", (b) "Madde hafifçe gözden geçirilmeli", (c) "Madde ciddi olarak gözden geçirilmeli" ve (d) "Madde uygun değil" şeklinde dörtlü derecelendirmektedir. Bu teknikte (a) ve (b) seçeneğini işaretleyen uzmanların sayısı toplam uzman sayısına bölünerek maddeye ilişkin "kapsam geçerlik indeksi" (KGI) elde edilmektedir ve bu değer 0.80 değeri ölçüt olarak kabul edilmektedir (s. 3). 
Tablo 2

Ölçek maddelerinin uzman görüşleri doğrultusunda kapsam geçerlik oranları

\begin{tabular}{|c|c|c|c|c|c|c|c|c|c|c|c|}
\hline Madde & 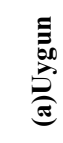 & 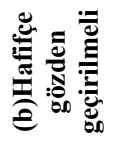 & 冚 & 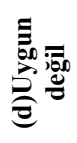 & $\begin{array}{c}\text { Kapsam } \\
\text { geçerlik } \\
\text { oranı }\end{array}$ & Madde & స్త్ర & 胥 & 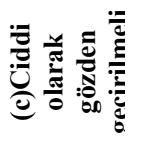 & 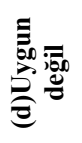 & $\begin{array}{c}\text { Kapsam } \\
\text { geçerlik } \\
\text { oranı }\end{array}$ \\
\hline 1 & 5 & 0 & 0 & 0 & 1.00 & 25 & 5 & 0 & 0 & 0 & 1.00 \\
\hline 2 & 5 & 0 & 0 & 0 & 1.00 & 26 & 5 & 0 & 0 & 0 & 1.00 \\
\hline 3 & 5 & 0 & 0 & 0 & 1.00 & 27 & 5 & 0 & 0 & 0 & 1.00 \\
\hline 4 & 5 & 0 & 0 & 0 & 1.00 & 28 & 5 & 0 & 0 & 0 & 1.00 \\
\hline 5 & 5 & 0 & 0 & 0 & 1.00 & 29 & 5 & 0 & 0 & 0 & 1.00 \\
\hline 6 & 5 & 0 & 0 & 0 & 1.00 & 30 & 5 & 0 & 0 & 0 & 1.00 \\
\hline 7 & 5 & 0 & 0 & 0 & 1.00 & 31 & 5 & 0 & 0 & 0 & 1.00 \\
\hline 8 & 5 & 0 & 0 & 0 & 1.00 & 32 & 5 & 0 & 0 & 0 & 1.00 \\
\hline 9 & 5 & 0 & 0 & 0 & 1.00 & 33 & 5 & 0 & 0 & 0 & 1.00 \\
\hline 10 & 5 & 0 & 0 & 0 & 1.00 & 34 & 5 & 0 & 0 & 0 & 1.00 \\
\hline 11 & 4 & 1 & 0 & 0 & 1.00 & 35 & 5 & 0 & 0 & 0 & 1.00 \\
\hline 12 & 5 & 0 & 0 & 0 & 1.00 & 36 & 5 & 0 & 0 & 0 & 1.00 \\
\hline 13 & 5 & 0 & 0 & 0 & 1.00 & 37 & 5 & 0 & 0 & 0 & 1.00 \\
\hline 14 & 5 & 0 & 0 & 0 & 1.00 & 38 & 5 & 0 & 0 & 0 & 1.00 \\
\hline 15 & 5 & 0 & 0 & 0 & 1.00 & 39 & 5 & 0 & 0 & 0 & 1.00 \\
\hline 16 & 5 & 0 & 0 & 0 & 1.00 & 40 & 5 & 0 & 0 & 0 & 1.00 \\
\hline 17 & 5 & 0 & 0 & 0 & 1.00 & 41 & 5 & 0 & 0 & 0 & 1.00 \\
\hline 18 & 5 & 0 & 0 & 0 & 1.00 & 42 & 5 & 0 & 0 & 0 & 1.00 \\
\hline 19 & 4 & 1 & 0 & 0 & 1.00 & 43 & 5 & 0 & 0 & 0 & 1.00 \\
\hline 20 & 4 & 1 & 0 & 0 & 1.00 & 44 & 5 & 0 & 0 & 0 & 1.00 \\
\hline 21 & 5 & 0 & 0 & 0 & 1.00 & 45 & 5 & 0 & 0 & 0 & 1.00 \\
\hline 22 & 5 & 0 & 0 & 0 & 1.00 & 46 & 5 & 0 & 0 & 0 & 1.00 \\
\hline 23 & 5 & 0 & 0 & 0 & 1.00 & 47 & 5 & 0 & 0 & 0 & 1.00 \\
\hline 24 & 4 & 1 & 0 & 0 & 1.00 & & & & & & \\
\hline
\end{tabular}

Tablo 2'ye bakıldığında, beş öğretim üyesinin değerlendirmelerine göre ölçekteki tüm maddelerin kapsam geçerlik oranlarının en yüksek değer olan 1.00 olduğu görülmektedir. Bu bağlamda hesaplanan değerlerin asgari değerden (0.80) fazla ve en yüksek değerde olması uzmanlar arasında uyum olduğunu ve kapsam geçerliği açısından ölçekten madde atılmaması gerektiğini göstermektedir. Daha sonra oluşturulan ölçeğe, amacı ve cevaplama şeklini açıklayan bir yönerge eklenmiş ve yönergenin ardından ölçekteki maddeler sıralanmıştır. Ölçekteki her ifade için, "tamamen katıllyorum", "katıllyorum”, "kararsızım”, "katılmıyorum” ve "kesinlikle katılmıyorum” olmak üzere 5'li likert kullanılmıştır.

\section{2. Ölçme Aracının Güvenirlik Çalışması}

Büyüköztürk (2008)'e göre madde analizinde madde toplam korelasyon katsayısının 0.70-1.00 arasında olması yüksek, 0.70-0.30 arasında olması orta, 0.30-0.00 arasında olması ise, düşük düzeyde bir ilişki olarak tanımlanmaktadır (s. 32). Bu nedenle, 47 maddeden oluşan ölçeğe uygulanan madde analizi sonucunda madde toplam korelasyon katsayısı 0,30'un altında olan 11,13,14,17, 18, 31 ve 45. maddelerin ölçekten çıkarılmasıyla ölçek maddelerinin sayısı 40'a düşmüştür. 47 maddeye ilişkin istatistik değerlerine Tablo 3'de yer verilmiştir.

Tablo 3

Madde ortalama, madde standart sapma ve madde toplam korelasyon değerleri

\begin{tabular}{|c|c|c|c|c|c|c|c|}
\hline 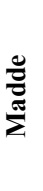 & 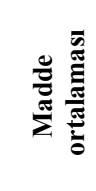 & 冚 冚 & 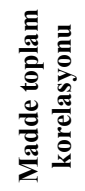 & 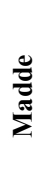 & 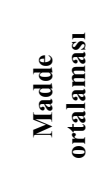 & 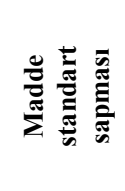 & 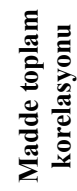 \\
\hline 1 & 4.8036 & .49440 & .365 & 25 & 4.1321 & 1.05428 & .368 \\
\hline 2 & 4.7429 & .60312 & .335 & 26 & 3.8429 & 1.10243 & .532 \\
\hline 5 & 4.4500 & .81055 & .539 & 29 & 4.4929 & .85086 & .611 \\
\hline 6 & 4.3107 & .99094 & .455 & 30 & 4.0929 & 1.07694 & .472 \\
\hline 7 & 3.7000 & 1.16828 & 374 & 31 & 2.9929 & 1.16087 & .084 \\
\hline 8 & 4.6071 & .82259 & .576 & 32 & 4.0000 & 1.07430 & .403 \\
\hline 9 & 4.7286 & .71685 & .457 & 33 & 4.0714 & 1.04482 & .482 \\
\hline 10 & 3.9643 & 1.00473 & .455 & 34 & 4.4857 & .84655 & .512 \\
\hline
\end{tabular}


Tablo 3'ün devamı

\begin{tabular}{|c|c|c|c|c|c|c|c|}
\hline$\underbrace{}_{\substack{\tilde{T}\\
}}$ & 导 & 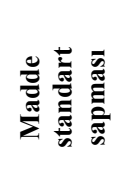 & 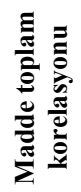 & $\frac{\stackrel{0}{\tilde{T}}}{\sum}$ & 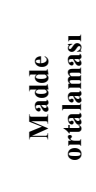 & 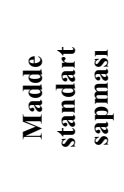 & 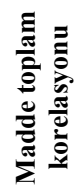 \\
\hline 14 & 3.9071 & 1.02929 & .181 & 38 & 3.7429 & 1.13195 & .434 \\
\hline 15 & 4.1821 & 1.07047 & .500 & 39 & 4.2393 & .95596 & .516 \\
\hline 16 & 4.2714 & 1.02193 & .436 & 40 & 4.3893 & .91300 & .558 \\
\hline 17 & 3.8714 & 1.11261 & .213 & 41 & 4.2857 & 1.02852 & .514 \\
\hline 18 & 3.1393 & 1.24660 & .269 & 42 & 4.5500 & .85362 & .573 \\
\hline 19 & 4.0464 & .97715 & .573 & 43 & 4.3036 & .89442 & .476 \\
\hline 20 & 4.1821 & .93078 & .531 & 44 & 3.5536 & 1.16274 & .365 \\
\hline 21 & 3.7857 & 1.05942 & .484 & 45 & 2.8321 & 1.23438 & .041 \\
\hline 22 & 4.2929 & .91578 & .634 & 46 & 3.6000 & 1.19617 & .380 \\
\hline 23 & 4.0321 & 1.02777 & .440 & 47 & 3.8679 & 1.20351 & .450 \\
\hline 24 & 4.3607 & .89716 & .589 & & & & \\
\hline
\end{tabular}

7 maddenin ölçekten çıkarılması ile 40 maddeye düşen ölçeğin Cronbach Alfa Güvenirlik Katsayısı $(\alpha)=0,925$ bulunmuştur. Kalaycı (2016) güvenirlik katsayısına ilişkin ölçüt değerleri; " $0.00<\alpha<0.40$ olduğu zaman ölçek güvenilir değil, $0.41<\alpha<0.60$ olduğu zaman ölçek düşük güvenirlikte, $0.61<\alpha<0.80$ olduğu zaman ölçek orta düzeyde güvenilir ve $0.81<\alpha<1.00$ olduğu zaman ölçek yüksek düzeyde güvenilir" şeklinde ifade etmektedir (s. 405). Bu ölçüt değerler dikkate alındığında, ölçeğin yüksek düzeyde güvenirlik katsayısına sahip olduğu ve özengen çalgı eğitimine yönelik güdülenmenin belirlenmesinde güvenirlik düzeyi yüksek ölçme sonuçlarına ulaşılabileceğini göstermektedir. 40 maddelik ölçeğin Cronbach Alfa Güvenirlik Katsayısına ilişkin değerlere Tablo 4'de yer verilmiştir.

Tablo 4

Cronbach alfa güvenirlik testi tablosu

\begin{tabular}{cc}
\hline Madde Sayısı & Cronbach Alfa Güvenirlik Katsayısı \\
\hline 40 & 0.925 \\
\hline
\end{tabular}

\section{3. Ölçme Aracının Geçerlik Çalışması}

7 maddenin madde analizi sonrasında ölçekten çıkarılmasıyla 40 maddeye düşen veri setinin faktör analizine uygunluğunun belirlenebilmesi için Kaiser-Meyer-Olkin (KMO) Örneklem Yeterliliği Testi ve Barlett Küresellik Testinden yararlanılmıştır. Gürbüz ve Şahin (2016)'in de belirttiği gibi KMO değerinin 0.60 ve üstünde olması örneklemin faktör analizi için yeterli olduğunu göstermektedir (s. 311). Durmuş, Yurtkoru ve Çinko (2016) ise KMO örneklem yeterliğinin kabul edilebilir alt sınırının 0,50 olduğunu ve 0.80 ve yukarısı için KMO değerinin mükemmel kabul edildiğini belirtmektedir (s. 79-80). Diğer yandan Barlett Küresellik testi ise korelasyon matrisindeki ilişkilerin faktör analizi yapacak ölçüde yeterli olup olmadığını test etmektedir. Bu test sonucunun anlamlı olması $(p<0,05)$ değişkenler arası ilişkilerin oluşturduğu matrisin faktör analizi için anlamlı olduğunu ve faktör analizinin yapılabileceği anlamını taşımaktadır. 40 maddelik ölçeğin KMO değerinin 0,80 'nin üzerinde olması $(K M O=0,889)$ ve Barlett testinin de 0.05 önem derecesinde anlamlı bulunmas1 $(p=0.000)$ veri setinin faktör analizine uygunluğunu göstermektedir. 40 maddelik ölçeğin KMO ve Barlett testi değerleri Tablo 5'de sunulmuştur.

Tablo 5

KMO ve Barlett testi tablosu

\begin{tabular}{lrl}
\hline Kaiser-Meyer-Olkin Testi (KMO) (Örneklem Yeterliliği Testi) & & 0.889 \\
\hline Bartlett Testi (Bartlett's Test) (Bartlett Küresellik Testi) & Ki Kare & p \\
\end{tabular}

Faktör analizinde kaç faktörün ya da boyutun çıkarılacağına karar verilirken çeşitli yaklaşımları göz önünde bulundurmak gerekmektedir. Araştırmacılar genellikle bu yaklaşımlardan birkaçını birlikte düşünerek faktör sayısına karar vermektedirler. Örneğin Kaiser ölçütü olarak bilinen öz değer yaklaşımına göre, öz değeri 1'in üzerinde olan faktör sayısı dikkate alınmalıdır. Ancak bu yaklaşım madde sayısının az ya da çok olduğu durumlarda güvenilir sonuçlar verememektedir (Gürbüz ve Şahin, 2016, s. 313). Çokluk, Şekercioğlu ve Büyüköztürk (2010)'ün de belirttiği gibi faktör sayısını belirlemede diğer bir yaklaşım da Cattell tarafindan önerilen yamaç-serpinti grafiğidir (s. 192-193). Bu yaklaşımda faktörlerin öz değerlerine göre en fazla açıklayıcılığa sahip faktörler dikkate alınarak, eğri eğiminin plato (düzleşme) yapmaya başladığı noktaya bakılarak faktör sayısına karar verilir. Açıklanan varyans oranı da araştırmacının faktör sayısına karar verirken göz önüne bulundurması gereken bir başka yaklaşımdır. Araştırmacının amacına bağlı olarak açıklanan toplam varyansa katkı sağlayan faktörler dikkate alınmalıdır. Diğer bir yandan faktörlere ilişkin varyans değerlerinin 
birbirine yaklaştığı noktanın da faktör sayısını belirlemede bir gösterge olduğu bilinmektedir. Bu durumda faktör varyans değerlerinin birbirlerine yaklaştığı nokta, faktör belirleme noktası olarak düşünülebilir. Çünkü bu noktadan sonraki faktörlerin varyansa yaptıkları katkı hemen hemen aynıdır (Büyüköztürk, 2008, s. 125). Faktör sayısına karar vermede bir başka yaklaşım da araştırmacının araştırmaya ilişkin kuramsal yapı doğrultusunda faktör sayısına kendisinin karar vermesidir (Gürbüz ve Şahin, 2016, s. 313).

Tüm bu yaklaşımlara dayanarak ölçeğin faktör analizi sonuçları doğrultusunda faktörlerin varyans değerleri ve yamaç serpinti grafiği incelenmiş, ölçek bileşenlerinden 10'unun öz değerlerinin 1'in üzerinde olduğu anlaşılmıştır. Ancak 5. bileşenden itibaren varyans değerlerinin birbirine yakınlaşması ve yamaç serpinti grafiğinde de eğri eğiminin plato (düzleşme) yapmaya başlaması nedeniyle 5. nokta faktör belirleme noktası olarak belirlenmiştir. Böylece özengen çalgı eğitimine yönelik güdülenme ölçeğine ilişkin maddelerin 5 faktör altında toplanması uygun görülmüştür.

Gürbüz ve Şahin (2016)'e göre faktör yüklerinin genel olarak en az 0,32'nin üzerinde olması önerilmektedir (s. 312). Ancak araştırmacı faktörlerin mümkün olduğunca güçlü maddelerden oluşmasını arzu ediyorsa yük değerinin yüksek tutulması önerilmektedir. Diğer yandan Büyüköztürk (2008) uygulamada az sayıda madde için faktör yük değeri sınırının 0.30'a kadar indirilebileceğini ancak faktör yük değerinin 0.45 ya da daha yüksek olmasının seçim için iyi bir ölçüt olduğunu belirtmektedir (s. 124). Bu nedenle ölçeğin faktör analizinde faktör yük değeri sınırı 0.45 olarak belirlenmiştir.

Bir maddenin faktörlerdeki en yüksek yük değeri ile bu değerden sonra en yüksek olan yük değeri arasındaki farkın olabildiğince yüksek olması beklenir. Yüksek iki yük değeri arasındaki farkın en az 0,10 olması önerilir. Çok faktörlü bir yapıda, birden çok faktörde yüksek yük değeri veren madde binişik bir madde olarak tanımlanır ve ölçekten çıkarılması düşünülebilir (Büyüköztürk, 2008, s. 125). Ölçeğin faktör analizinde Dönüşümlü Faktör Yükleri sonuçlarına göre birden fazla faktörde binişik yapıda olan ve güvenirliği düşüren 7, 12, 15, 19, 20, 23, $28,29,30,35,37,38,39,41$ ve 42 . maddelerin yüksek iki yük değerleri arasındaki farkın 0,10'dan az olduğu belirlenmiş ve bu 15 maddenin ölçekten çıkarılmasıyla kalan 25 madde ile ölçeğe nihai şekli verilmiştir.

Tablo 6, 7, 8 ve 9'da 47 maddeden oluşan ön deneme formuna uygulanan madde analizi ve açımlayıcı faktör analizi sonucunda 22 maddenin çıkarılması ile oluşturulan 25 maddelik özengen çalgı eğitimine yönelik güdülenme ölçeğinin son şekline ilişkin bulgu ve yorumlara yer verilmiştir.

Tablo 6

Ölçek maddelerine ilişkin istatistikler

\begin{tabular}{|c|c|c|c|c|c|}
\hline $\begin{array}{l}\text { Madde } \\
\text { No }\end{array}$ & Ölçek Maddeleri & $\begin{array}{c}\text { Madde } \\
\text { ortalaması }\end{array}$ & $\begin{array}{c}\text { Madde } \\
\text { standart } \\
\text { sapması } \\
\end{array}$ & $\begin{array}{c}\text { Madde } \\
\text { toplam } \\
\text { korelasyonu }\end{array}$ & $\begin{array}{c}\text { Madde silme } \\
\text { güvenirlik } \\
\text { katsayısı }\end{array}$ \\
\hline 1 & Çalgı çalmayı öğrenmek boşa zaman harcamaktır. & 4.8036 & .49440 & .371 & .875 \\
\hline 2 & Çalgı çalmayı mecbur olduğum için öğreniyorum. & 4.7429 & .60312 & .342 & .875 \\
\hline 3 & Çalgı çalmayı öğrenmek sıkıcıdır. & 4.6786 & .62525 & .499 & .872 \\
\hline 4 & Ailem zorlamasa çalgı çalmayı öğrenmek istemezdim. & 4.6107 & .84787 & .462 & .872 \\
\hline 5 & Çalgıma çalışmamak için bahaneler uydururum. & 4.4500 & .81055 & .511 & .871 \\
\hline 6 & Çalgımla ilgili ödevlerimin bana ne yarar sağlayacağını bilmiyorum. & 4.3107 & .99094 & .443 & .872 \\
\hline 8 & Çalg1 dersinde yeni şeyler öğrenmek beni mutlu eder. & 4.6071 & .82259 & .586 & .869 \\
\hline 9 & Çalgımda başarılı olunca kendimi mutlu hissederim. & 4.7286 & .71685 & .481 & .872 \\
\hline 10 & Çalgı dersinden çıkınca derste öğrendiklerimi hemen çalışmak isterim. & 3.9643 & 1.00473 & .427 & .873 \\
\hline 16 & Çalgım ile ilgili müzikleri internetten bulmak ve dinlemek ilgimi çeker. & 4.2714 & 1.02193 & .396 & .874 \\
\hline 21 & $\begin{array}{l}\text { Çalgı derslerinde kullanılan materyalleri (nota, eser, parça, türkü vb.) } \\
\text { anlamakta zorlanırım. }\end{array}$ & 3.7857 & 1.05942 & .483 & .871 \\
\hline 22 & Öğretmenimin verdiği ödevleri çalabilmek kendime olan güvenimi arttırır. & 4.2929 & .91578 & .623 & .868 \\
\hline 24 & $\begin{array}{l}\text { Çalgı derslerindeki uygulamaları (eser, etüd vb.) tamamladığımda başarılı } \\
\text { olduğumu hissederim. }\end{array}$ & 4.3607 & .89716 & .590 & .869 \\
\hline 25 & $\begin{array}{l}\text { Çalgı derslerinde kullanılan notaların kolay okunabilir olması dikkatimi } \\
\text { arttırır. }\end{array}$ & 4.1321 & 1.05428 & .372 & .874 \\
\hline 26 & Çalgım ile ilgili sanatçıları her zaman takip ederim. & 3.8429 & 1.10243 & .459 & .872 \\
\hline 27 & Düzeyimin üzerindeki parçalarla uğraşmak istemem. & 3.6000 & 1.19016 & .318 & .877 \\
\hline 32 & $\begin{array}{l}\text { Çalgı çalabilmenin beni diğer insanlardan farklı kılan bir özellik olduğunu } \\
\text { düşünüyorum. }\end{array}$ & 4.0000 & 1.07430 & .398 & .874 \\
\hline 33 & Çalgı çalan arkadaşlarımın hangi parçaları çaldıklarını merak ederim. & 4.0714 & 1.04482 & .433 & .873 \\
\hline 34 & Ailem çalgı çalmam konusunda beni destekler. & 4.4857 & .84655 & .510 & .871 \\
\hline 36 & Çalgı derslerindeki alıştırma ve uygulamalar zordur. & 3.3893 & 1.11774 & .425 & .873 \\
\hline 40 & Çalgı öğrenmeye ayırdığım zamanı başka bir uğraşla geçirmek isterdim. & 4.3893 & .91300 & .555 & .869 \\
\hline 43 & Ailem çalgı çaldığım için benimle gurur duyuyor. & 4.3036 & .89442 & .497 & .871 \\
\hline 44 & Çalgı çalma konusunda başarılı olduğum için her çalgıyı öğrenebilirim. & 3.5536 & 1.16274 & .383 & .874 \\
\hline 46 & $\begin{array}{l}\text { İlk defa çalacağım bir parçayı öğrenirken yaşadığım zorluk çalgı çalma } \\
\text { isteğimi azaltır. }\end{array}$ & 3.6000 & 1.19617 & .328 & .876 \\
\hline 47 & $\begin{array}{l}\text { Çalgı çalmayı öğrenmek tahminimden daha zor olduğu için } \\
\text { öğrenemeyeceğim hissine kapılırım. }\end{array}$ & 3.8679 & 1.20351 & .445 & .873 \\
\hline
\end{tabular}


Tablo 6'da 25 maddeden oluşan nihai ölçeğin maddelerine ilişkin madde ortalama, madde standart sapma, madde toplam korelasyon ve madde silme güvenirlik katsayısı değerlerine yer verilmiştir. Maddelerin madde silme güvenirlik katsayısı değerlerine bakıldığında, güvenirlik katsayısını hiçbir maddenin olumsuz olarak etkilemediği anlaşılmaktadır. Yine tablo 5'e göre 25 maddeden oluşan ölçeğin Cronbach Alfa Güvenirlik Katsayısı 0.877 bulunmuştur. Özdamar (1999)'ın da belirttiği gibi güvenirlik katsayısına ilişkin ölçüt değerler 0.81 ile 1.00 arasında bir değer aldığında ölçek yüksek düzeyde güvenilir kabul edilmektedir (aktaran Yaşar, 2014, s. 63). Bu ölçüt değerler dikkate alındığında, 25 maddeden oluşan ölçeğin yüksek düzeyde güvenirlik katsayısına sahip olduğu ve özengen çalgı eğitimine yönelik güdülenmenin belirlenmesinde güvenirlik düzeyi yüksek ölçme sonuçlarını gösterebileceği anlaşılmaktadır.

Tablo 7

Açımlayıcı faktör analizine ilişkin açıklanan toplam varyans değerleri

\begin{tabular}{|c|c|c|c|c|c|c|}
\hline & \multicolumn{3}{|c|}{ Bașlangıç Öz Değerleri } & \multicolumn{3}{|c|}{ Dönüştürülmüş Kareli Ağırlıklar Toplamı } \\
\hline Bileșen & Toplam & Açıklanan Varyans \% & Birikimli \% & Toplam & Açıklanan Varyans \% & Birikimli \% \\
\hline 1 & 6.832 & 27.330 & 27.330 & 3.473 & 13.892 & 13.892 \\
\hline 2 & 2.309 & 9.237 & 36.567 & 3.013 & 12.051 & 25.943 \\
\hline 3 & 1.738 & 6.951 & 43.518 & 2.658 & 10.630 & 36.573 \\
\hline 4 & 1.440 & 5.760 & 49.278 & 2.465 & 9.860 & 46.433 \\
\hline 5 & 1.257 & 5.028 & 54.305 & 1.968 & 7.872 & 54.305 \\
\hline 6 & .977 & 3.908 & 58.213 & & & \\
\hline 7 & .924 & 3.694 & 61.907 & & & \\
\hline 8 & .906 & 3.624 & 65.531 & & & \\
\hline 9 & .807 & 3.228 & 68.759 & & & \\
\hline 10 & .740 & 2.962 & 71.721 & & & \\
\hline 11 & .711 & 2.845 & 74.566 & & & \\
\hline 12 & .679 & 2.717 & 77.282 & & & \\
\hline 13 & .655 & 2.619 & 79.901 & & & \\
\hline 14 & .574 & 2.297 & 82.198 & & & \\
\hline 15 & .550 & 2.200 & 84.398 & & & \\
\hline 16 & .519 & 2.074 & 86.472 & & & \\
\hline 17 & .514 & 2.055 & 88.527 & & & \\
\hline 18 & .477 & 1.907 & 90.434 & & & \\
\hline 19 & .436 & 1.742 & 92.176 & & & \\
\hline 20 & .419 & 1.677 & 93.853 & & & \\
\hline 21 & .408 & 1.630 & 95.483 & & & \\
\hline 22 & .337 & 1.349 & 96.832 & & & \\
\hline 23 & .309 & 1.234 & 98.067 & & & \\
\hline 24 & .260 & 1.039 & 99.106 & & & \\
\hline 25 & .224 & .894 & 100.000 & & & \\
\hline
\end{tabular}

Özengen çalg1 eğitimine yönelik güdülenme ölçeğinin toplam varyans tablosuna göre, faktör analizine girmiş soru sayısı Bileşen sütununda yer almaktadır. Başlangıç Öz değerleri sütunundaki Toplam sütununa bakıldığında, 1'den büyük öz değere sahip 5 bileşenin bulunduğu görülmektedir. Bu durum ölçeğin 5 alt boyuttan oluştuğunu ortaya çıkarmaktadır. Dönüştürülmüş Kareli Ağırlıklar Toplamı sütununun altında yer alan Birikimli \% sütununa bakıldığında, 5 alt boyutun toplam varyansın \% 54.305'ini açıklandığı anlaşılmaktadır. Bu bulguya göre, ortaya çıkan 5 faktör, maddelerdeki toplam varyansı ve ölçeğe ilişkin varyansın çoğunu açıklamaktadır.

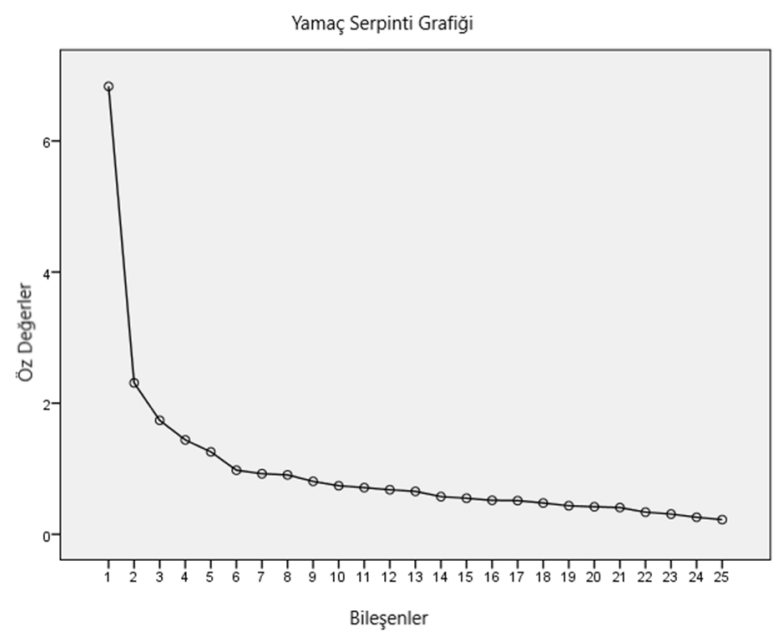

Şekil 1. Güdülenme ölçeği yamaç serpinti grafiği 
Özengen çalg1 eğitimi güdülenme ölçeğinin yamaç serpinti grafiği incelendiğinde, 5. bileşenden sonra varyans değerlerinin birbirlerine yakınlaştığı, eğri eğiminin düzleşmeye başladığı ve öz değerlerin de 1 'in altına düştüğü anlaşılmaktadır. Bu durum, ölçekteki faktör belirleme noktasının 5 olduğunu destekler niteliktedir.

Tablo 8

Açımlayıcı faktör analizine ilişkin faktör döndürme sonuçları

\begin{tabular}{|c|c|c|c|c|c|}
\hline \multirow[b]{2}{*}{ Maddeler } & \multicolumn{5}{|c|}{ Faktörler } \\
\hline & 1. Faktör & 2. Faktör & 3. Faktör & 4. Faktör & 5. Faktör \\
\hline 8 & .765 & .074 & .187 & .060 & .270 \\
\hline 24 & .690 & .163 & .106 & .225 & .165 \\
\hline 40 & .639 & .242 & .282 & .120 & -.061 \\
\hline 34 & .624 & .062 & .215 & .385 & -.174 \\
\hline 9 & .614 & .124 & .151 & -.090 & .390 \\
\hline 25 & .609 & .069 & -.136 & .160 & .171 \\
\hline 22 & .595 & .178 & .122 & .339 & .235 \\
\hline 2 & .087 & .743 & .001 & -.060 & .104 \\
\hline 5 & .149 & .688 & .244 & .201 & -.034 \\
\hline 4 & .299 & .673 & .113 & .066 & -.103 \\
\hline 1 & .066 & .651 & .059 & .046 & .165 \\
\hline 6 & .011 & .622 & .250 & .124 & .173 \\
\hline 3 & .125 & .621 & .286 & .035 & .208 \\
\hline 47 & .134 & .171 & .724 & .061 & .007 \\
\hline 46 & .130 & .176 & .688 & -.140 & -.065 \\
\hline 36 & .145 & .127 & .629 & .168 & -.024 \\
\hline 21 & .063 & .110 & .627 & .230 & .255 \\
\hline 27 & .020 & .092 & .515 & .124 & .082 \\
\hline 43 & .262 & .017 & .216 & .709 & .038 \\
\hline 32 & .173 & .048 & .083 & .674 & .030 \\
\hline 33 & .283 & .121 & -.070 & .648 & .131 \\
\hline 44 & -.046 & .071 & .214 & .623 & .250 \\
\hline 10 & .153 & .109 & .222 & .074 & .708 \\
\hline 16 & .284 & .126 & -.057 & .112 & .677 \\
\hline 26 & .167 & .212 & -.032 & .361 & .597 \\
\hline
\end{tabular}

Ölçeğin açımlayıcı faktör analizine ilişkin faktör döndürme sonuçları incelendiğinde, ölçek maddeleri hangi faktör altında en büyük faktör yüküne sahipse maddelerin o faktör altında yer aldığı anlaşılmaktadır. Faktör analizi sonucunda elde edilen faktör döndürme sonuçlarına göre, 8, 24, 40, 34, 9, 25 ve 22. maddelerin birinci faktör altında, 2, 5, 4, 1, 6 ve 3. maddelerin ikinci faktör altında, 47, 46, 36, 21 ve 27. maddelerin üçüncü faktör altında, 43, 32, 33 ve 44. maddelerin dördüncü faktör altında ve 10, 16 ve 26 . maddelerin ise beşinci faktör altında yer aldığı görülmektedir.

Tablo 9

Güdülenme ölçeği faktör ve güvenirlik analizi sonuçları

\begin{tabular}{|c|c|c|c|}
\hline $\begin{array}{c}\text { Faktörün } \\
\text { Adı }\end{array}$ & $\begin{array}{c}\text { Ölçek } \\
\text { Maddeleri }\end{array}$ & $\begin{array}{c}\text { Açıklanan } \\
\text { Varyans } \\
(\%)\end{array}$ & $\begin{array}{c}\text { Güvenirlik } \\
\text { Cronbach Alfa } \\
(\alpha)\end{array}$ \\
\hline 1.FAKTÖR - Mutluluk & $8,24,40,34,9,25,22$ & 27.330 & 0.835 \\
\hline 2.FAKTÖR - İsteksizlik & $2,5,4,1,6,3$ & 9.237 & 0.785 \\
\hline 3.FAKTÖR - Zorluk Yaşama & $47,46,36,21,27$ & 6.951 & 0.716 \\
\hline 4.FAKTÖR - Sosyal Çevreyle Etkileşim & $43,32,33,44$ & 5.760 & 0.697 \\
\hline 5.FAKTÖR - İlgi & $10,16,26$ & 5.028 & 0.672 \\
\hline
\end{tabular}

Faktörler, barındırdıkları maddelerin amaçları, ifadeleri ve konu ile ilgili literatür dikkate alınarak isimlendirilmiştir. Faktörlere verilen isimler, her faktörün altında yer alan maddeler, faktörlerin açıkladıkları varyans ve yine faktörlerin güvenirlik katsayıları Tablo 8 aracılığı ile sunulmuştur. Tablo 8'e göre "Mutluluk" olarak isimlendirilen 1. Faktör 8, 24, 40, 34, 9, 25 ve 22. maddeler olmak üzere 7 maddeyi kapsamaktadır. Bu faktör toplam varyansın \% 27.330'unun oluşturmaktadır ve faktörün güvenirlik katsayısı 0.835 olarak bulunmuştur. 2. Faktör "İsteksizlik" olarak isimlendirilmiştir ve faktör 2, 5, 4, 1, 6 ve 3. maddelerden oluşmaktadır. 2. Faktör toplam varyansın \% 9.237 açıklamaktadır ve faktörün güvenirlik katsayısı 0.785 olarak bulunmuştur. "Zorluk Yaşama" olarak isimlendirilen 3. Faktör 47, 46, 36, 21 ve 27 olmak üzere 5 maddeden oluşmaktadır. 3. Faktör toplam varyansın \% 6.951'ini açıklamaktadır ve faktörün güvenirlik katsayısı 0.716 olarak bulunmuştur. Ölçekteki 4. Faktör "Sosyal Çevreyle Etkileşim" adını taşımaktadır. Bu faktör 43, 32 , 33 ve 44 olmak üzere 4 maddeyi kapsamaktadır. Faktör toplam varyansın \% 5.760'sını açıklamaktadır ve faktörün güvenirlik katsayısı 0.697'dir. Son faktör olan 5. Faktör "İlgi” olarak adlandırılmıştır. Bu faktör 10, 16 ve 26. maddeler olmak üzere 3 maddeyi kapsamaktadır. İlgili faktör toplam varyansın \% 5.028'ini oluşturmaktadır ve faktörün güvenirlik katsayısı 0.672 olarak bulunmuştur. 


\section{Sonuç}

Özengen çalgı eğitimine yönelik güdülenme ölçeğinin geliştirilmesinin amaçlandığı bu çalışmada, geliştirilmeye çalışılan ölçme aracının geçerlik ve güvenirliğini belirlemek amacıyla madde analizi ve açımlayıcı faktör analizinden yararlanılmıştır.

Analiz öncesinde 47 maddeden oluşan ölçeğin madde analizinde madde-test korelasyon katsayısı 0.30 'un altında olan $11,13,14,17,18,31$ ve 45. maddelerin ölçekten çıkarılmasıyla ölçek maddelerinin sayısı 40'a düşmüştür. Ölçeğin yapısal geçerliğinin belirlenmesi amacıyla temel bileşenler analizi ve varimaks eksen döndürme tekniği kullanılarak açımlayıcı faktör analizi uygulanmıştır. 40 maddeye düşen veri setinin faktör analizine uygunluğunun belirlenebilmesi için Kaiser-Meyer-Olkin (KMO) Örneklem Yeterliliği Testi ve Barlett Küresellik Testinden yararlanılmıştır. 40 maddelik ölçeğin KMO değerinin 0.80 'nin üzerinde olması $(K M O=0.889)$ ve Barlett testinin de 0.05 önem derecesinde anlamlı bulunması $(p=0.000)$ veri setinin faktör analizine uygunluğunu göstermiştir. Tüm bu yaklaşımlara dayanarak ölçeğin faktör analizi sonuçları doğrultusunda faktörlerin varyans değerleri ve yamaç serpinti grafiği incelenmiş, ölçek bileşenlerinden 10'unun öz değerlerinin 1'in üzerinde olduğu anlaşılmıştır. Ancak 5. bileşenden itibaren varyans değerlerinin birbirine yakınlaşması ve yamaç serpinti grafiğinde de eğri eğiminin plato (düzleşme) yapmaya başlaması nedeniyle 5. nokta faktör belirleme noktası olarak belirlenmiştir. Böylece özengen çalgı eğitimine yönelik güdülenme ölçeğine ilişkin maddelerin 5 faktör altında toplanması uygun görülmüştür. Faktör analizinde faktör yük değerinin 0.45 ya da daha yüksek olmasının seçim için iyi bir ölçüt olduğunu bilinmektedir. Bu nedenle ölçeğin faktör analizinde faktör yük değeri sınırı 0.45 olarak belirlenmiştir. Ölçeğin faktör analizinde dönüşümlü faktör yükleri sonuçlarına göre birden fazla faktörde binişik yapıda olan ve güvenirliği düşüren 15 maddenin yüksek iki yük değerleri arasındaki farkın 0.10 'dan az olduğu belirlenmiş maddeler ölçekten çıkarılmıştır.

Yeniden yapılan açımlayıcı faktör analizi sonuçlarına göre, 25 maddeden oluşan ölçeğin 5 faktörlü bir yapıda olduğu ve faktörlerin toplam varyansın \% 54.305'ini açıkladığı belirlenmiştir. Faktörler altına yüklenen maddeler ve kuramsal beklentiden yola çıkılarak ölçekteki faktörler; Mutluluk, isteksizlik, zorluk yaşama, sosyal çevreyle etkileşim ve ilgi olarak adlandırılmıştır. Özengen çalgı eğitimi güdülenme ölçeğinin faktörlerine yönelik olarak, 1. Faktör (Mutluluk) toplam varyansın \% 27.330'unu, 2. Faktör (İsteksizlik) \% 9.237'sini, 3. Faktör (Zorluk Yaşama) \% 6.951'ini, 4. Faktör (Sosyal Çevreyle Etkileşim) \% 5.760'ını ve 5. Faktör (İlgi) de \% 5.028'ini açıklamıştır. Bir diğer yandan, 25 maddeden oluşan güdülenme ölçeğinin Cronbach Alfa katsayısı 0.877 bulunmuştur. Cronbach Alfa katsayısının yüksek çıkması, ölçme aracında yer alan güdülenme maddeleri arasında yüksek düzeyde bir uyum olduğunu göstermiştir. Ölçeğin faktörlerine ilişkin güvenirlik katsayıları ise sırasıyla birinci faktör $\alpha=0.835$, ikinci faktör $\alpha=0.785$, üçüncü faktör $\alpha=0.716$, dördüncü faktör $\alpha=0.697$ ve beşinci faktör $\alpha=0.672$ olarak belirlenmiştir.

Sonuç olarak, özengen çalgı eğitimine yönelik güdülenme ölçeğinin psikometrik özellikleri dikkate alındığında, özengen çalgı eğitimi alan bireylerin bu eğitime yönelik güdülenmelerinin ölçülmesinde geçerli ve güvenilir bir şekilde kullanılabilecek bir ölçme aracının geliştirildiği düşünülmektedir.

\section{Kaynakça}

Bakırcıoğlu, R. (2012). Ansiklopedik eğitim ve psikoloji sözlüğ̈̈. Ankara: Anı Yayıncılık.

Bingöl, F. (2010). Özengen gitar eğitiminde parmak hazırlamalı öğretim yönteminin öğrencilerin gitar çalmadaki başarılarına etkisi (Özel Çağlar Müzik Kursu örneği) (Yüksek lisans tezi). YÖK tez veri tabanından erişildi (Tez No. 278169).

Büyüköztürk, Ş. (2008). Sosyal bilimler için veri analizi el kitabı (9. baskı). Ankara: Pegem Akademi.

Cope, P. (2002). Informal learning of musical instruments: the importance of social context. Music Education Research, 4(1), 93-104. doi: https://doi.org/10.1080/14613800220119796

Çağlar, E. (2017). Türkiye'de özengen (amatör) keman eğitimi alanında görev yapan eğitimcilerin keman derslerine ilişkin görüşlerinin değerlendirilmesi: Ankara ili örneği. Journal of Current Researches on Educational Studies, 7(2), 113-124. doi: https://doi.org/10.26579/jocures-7.2.8

Çoban, S., \& Çalışkan, T. (2019). Bireysel çalgı eğitimi dersi güdülenme ölçeği (ÇDGÖ) geçerlik ve güvenirlik çalışması. Eğitim Kuram ve Uygulama Araştırmaları Dergisi, 5(1), 100-112. Erişim adresi: https://dergipark.org.tr/tr/download/article-file/705701

Çokluk, Ö., Şekercioğlu, G., \& Büyüköztürk, Ş. (2010). Sosyal bilimler için çok değişkenli istatistik SPSS ve lisrel uygulamaları (1. baskı). Ankara: Pegem Akademi Yayınları.

Durmuş, B., Yurtkoru, S., \& Çinko, M. (2016). Sosyal bilimlerde SPSS'le veri analizi (6. bask1). İstanbul: Beta Basım Yayın. 
Evans, P. (2015). Self-determination theory: An approach to motivation in music education. Musicae Scientiae, 19(1), 65-83. doi: https://doi.org/10.1177/1029864914568044

Feng, S., \& Tuan, H. (2005). Using ARCS Model to promote 11th graders' motivation and achievement in learning about acids and bases. International Journal of Science and Mathematics Education, 3(3), 463-484. doi: https://doi.org/10.1007/s10763-004-6828-7

Gürbüz, S., \& Şahin, F. (2016). Sosyal bilimlerde araştırma yöntemleri (3. baskı). Ankara: Seçkin Yayıncılık.

Kalayc1, Ş. (2016). SPSS uygulamalı çok değişkenli istatistik teknikleri (7. baskı). Ankara: Asil Yayıncılık.

Karan, M. (2011). Özengen müzik ĕgitimi veren kurumlarda çalgı ĕgitimi alan öğrencilerin mesleki yönelimlerinin incelenmesi (Yüksek lisans tezi). YÖK tez veri tabanından erişildi (Tez No. 290600).

Koçel, T. (2014). İşletme yöneticiliği (15. bask1). İstanbul: Beta Basım.

Leung, B. W. (2008). Factors affecting the motivation of Hong Kong primary school students in composing music. International Journal of Music Education, 26(1), 47-62. doi: https://doi.org/10.1177/ 0255761407085649

Martin, A. J. (2004). School motivation of boys and girls: Differences of degree, differences of kind, or both?. Australian Journal of Psychology, 56(3), 133-146. doi: https://doi.org/10.1080/00049530412331283363

Özdek, A. (2006). Özengen müzik eğitimi veren kurumlarda klasik gitar eğitimi (Yüksek lisans tezi). YÖK tez veri tabanından erişildi (Tez No. 189394).

Ryan, R. M., \& Deci, E. L. (2000). Intrinsic and extrinsic motivations classic definitions and new drections. Contamparary Educational Psychology, 25(1), 54-67. doi: https://doi.org/10.1006/ceps.1999.1020

Seah, W. T. \& Bishop, A. J., (2000, April). Values in mathematics textbooks: A wiew throught the australasian regions. Paper Presented at the Annual Meeting of the American Educational Research Association, LA: New Orleans. Erişim adresi: http://citeseerx.ist.psu.edu/viewdoc/download?doi=10.1.1.539.6280\&rep= rep1\&type $=$ pdf

Semerci, Ç. (2010). Başarı odaklı motivasyon (bom) ölçeği’nin geliştirilmesi. E-Journal of New World Sciences Academy, 5(4), 2123-2133. Erişim adresi: https://dergipark.org.tr/en/download/article-file/185759

Sichivitsa, V. O. (2007). The influences of parents, teachers, peers and other factors on students' motivation in music. Research Studies in Music Education, 29, 55-68. Erişim adresi: https://pdfs.semanticscholar.org/ f692/63ad39e979b52def28fcd10c034afc5b59a7.pdf

Sungurtekin, M. (2010). Motivasyon ve çalgı eğitimindeki yeri. E-Journal of New World Sciences Academy, 5(1), 28-34. Erişim adresi: https://dergipark.org.tr/en/download/article-file/186621

Şen, E., \& Çoban, S. (2018). Zihin haritası tekniğinin keman eğitimi derslerinde kullanımının öğrencilerin bilişsel, devinişsel becerilerine ve tutumlarına etkisi. Eğitim ve Bilim, 43(194), 285-310. doi: http://dx.doi.org/10.15390/EB.2018.7623

Tepeli, H. (2018). Ankara'daki özengen müzik eğitimi veren kurumların çok yönlü incelenmesi (Yüksek lisans tezi). YÖK tez veri tabanından erişildi (Tez No. 527769).

Uçan, A. (2005). Müzik eğitimi temel kavramlar-ilkeler-yaklaşımlar (3. bask1). Ankara: Evrensel Müzik Evi.

Yaşar, M. (2014). İstatistiğe yönelik tutum ölçeği: geçerlilik ve güvenirlik çalışması. Pamukkale Üniversitesi Eğitim Fakültesi Dergisi, 36(2), 59-75. doi: http://doi.org/10.9779/PUJE64c

Yurdugül, H. (2005, Eylül). Ölçek geliştirme çalışmalarında kapsam geçerliği için kapsam geçerlik indekslerinin kullanılmasl. Pamukkale Üniversitesi Eğitim Fakültesi XIV. Ulusal Eğitim Bilimleri Kongresine sunulan bildiri, Pamukkale Üniversitesi, Denizli. Erişim adresi: http://yunus.hacettepe.edu.tr/ yurdugul/3/indir/PamukkaleBildiri.pdf 


\section{EK-1}

\section{Özengen Çalgı Eğitimine Yönelik Güdülenme Ölçeği}

\begin{tabular}{|c|c|c|c|c|c|c|}
\hline & ÖLÇEK MADDELERİ & 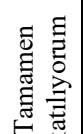 & 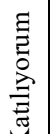 & 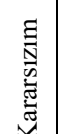 & 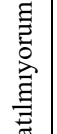 & 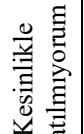 \\
\hline 1 & Çalgı çalmayı öğrenmek boşa zaman harcamaktır. & & & & & \\
\hline 2 & Çalg1 çalmayı mecbur olduğum için öğreniyorum. & & & & & \\
\hline 3 & Çalgı çalmayı öğrenmek sıkıcıdır. & & & & & \\
\hline 4 & Ailem zorlamasa çalgı çalmayı öğrenmek istemezdim. & & & & & \\
\hline 5 & Çalgıma çalışmamak için bahaneler uydururum. & & & & & \\
\hline 6 & Çalgımla ilgili ödevlerimin bana ne yarar sağlayacağını bilmiyorum. & & & & & \\
\hline 7 & Çalg1 dersinde yeni şeyler öğrenmek beni mutlu eder. & & & & & \\
\hline 8 & Çalgımda başarılı olunca kendimi mutlu hissederim. & & & & & \\
\hline 9 & Çalgı dersinden çıkınca derste öğrendiklerimi hemen çalışmak isterim. & & & & & \\
\hline 10 & Çalgım ile ilgili müzikleri internetten bulmak ve dinlemek ilgimi çeker. & & & & & \\
\hline 11 & $\begin{array}{l}\text { Çalgı derslerinde kullanılan materyalleri (nota, eser, parça, türkü vb.) anlamakta } \\
\text { zorlanırım. }\end{array}$ & & & & & \\
\hline 12 & Öğretmenimin verdiği ödevleri çalabilmek kendime olan güvenimi arttırır. & & & & & \\
\hline 13 & $\begin{array}{l}\text { Çalgı derslerindeki uygulamaları (eser, etüd vb.) tamamladığımda başarılı } \\
\text { olduğumu hissederim. }\end{array}$ & & & & & \\
\hline 14 & Çalgı derslerinde kullanılan notaların kolay okunabilir olması dikkatimi arttırır. & & & & & \\
\hline 15 & Çalgım ile ilgili sanatçıları her zaman takip ederim. & & & & & \\
\hline 16 & Düzeyimin üzerindeki parçalarla uğraşmak istemem. & & & & & \\
\hline 17 & $\begin{array}{l}\text { Çalgı çalabilmenin beni diğer insanlardan farklı kılan bir özellik olduğunu } \\
\text { düşünüyorum. }\end{array}$ & & & & & \\
\hline 18 & Çalgı çalan arkadaşlarımın hangi parçaları çaldıklarını merak ederim. & & & & & \\
\hline 19 & Ailem çalg1 çalmam konusunda beni destekler. & & & & & \\
\hline 20 & Çalg1 derslerindeki alıştırma ve uygulamalar zordur. & & & & & \\
\hline 21 & Çalgı öğrenmeye ayırdığım zamanı başka bir uğraşla geçirmek isterdim. & & & & & \\
\hline 22 & Ailem çalg1 çaldığım için benimle gurur duyuyor. & & & & & \\
\hline 23 & Çalgı çalma konusunda başarılı olduğum için her çalgıyı öğrenebilirim. & & & & & \\
\hline 24 & $\begin{array}{l}\text { İlk defa çalacağım bir parçayı öğrenirken yaşadığım zorluk çalgı çalma isteğimi } \\
\text { azaltır. }\end{array}$ & & & & & \\
\hline & $\begin{array}{l}\text { Çalgı çalmayı öğrenmek tahminimden daha zor olduğu için öğrenemeyeceğim } \\
\text { hissine kapılırım. }\end{array}$ & & & & & \\
\hline
\end{tabular}

